\title{
Geopolitics in Space and Time
}

Russia in Global Affairs Editor Alexander Solovyov talks with Vladimir $\boldsymbol{P}$. Lukin about the intellectual misery of political science, the will of people and the power of things, the reassessment of the Cold War and national interests, "the society of the spectacle" in the 21st century and the advance of artificial intelligence, about attempts to run away from present-day reality into the future, and many other disturbing modern tendencies.

- Do you agree that contemporary political scientists-Russian, Western or Chinese-seem to have all turned into doctrinarians or time-servers who sing along with the authorities and get trapped by one narrative?

- I would say that the word "doctrinarian" belongs to the specific Stalin-era political vocabulary. But you are absolutely right that there are many people who are much more eager to please the authorities than dig down to the truth. But this is how it has always been. However, now this has assumed a distorted and vulgar form, which is why it strikes the eye so much.

Soviet times produced a wonderful definition of socialist realismlaudation of the authorities in a way easy for them to understand. The latter is very important even though it is not so easy to please the boss and at the same time keep one's individuality. Mayakovsky suffered much for using forms which were hard to understand, Meyerkhold

Vladimir P. Lukin is a Russian diplomat, politician, and international relations expert; former Ombudsman of the Russian Federation (2004-2014), Research Professor at National Research University-Higher School of Economics. 
probably did, too. Comrade Stalin once famously remarked about two opposition activists of that time, actually not so much activists as just people who used to ask inopportune questions and did not fit into the extremely narrow and harsh mainstream where Soviet political thought circulated.

He said something like this: "Political freaks Shatskin and Lominadze have asked us which political slant is worse: right or left. And we tell them: both are worse."

So there are people like this, but this is not a substantive problem, it's a problem of morals, ethics, and values. This is an eternal problem, but also very modern at the same time. In fact, it is hard in the age of the Internet "to live in distant province, by the ocean."

- Is the desire to please the boss the only reason why the emerging narrative is so conformist?

- You know, there are two types of love for the boss: unselfish and selfish. The latter is clear: a person wants to get certain benefits for himself either mercantile or those that would match his ambitions. Unselfish love for the boss is what is called charisma. Sometimes it can be worked up to the state of ecstasy and it is closely connected with both reality and one's state of mind. I think we have seen an outburst of such unselfish love for the authorities in the last several years.

As a matter of fact, this occurs in many countries. There are those who are sincerely fond of Trump and there are those who feel affection for his opposites like Sanders. He is not their boss but he is a charismatic candidate for a considerable part of the U.S. population.

- In other words, it is more like a thirst for a symbol that would reflect certain aspirations of society or its groups?

- That's right. It is the personification of harmony in one's own heart in the first place. "I am him because he is me."

- Let us get back to more rational things. Just recently one of the political scientists criticized his colleagues, who have been trying to define the current situation using Cold War-era terms such 
as a new Cold War, a hybrid Cold War, and so on, of intellectual cowardice and laziness, of inability to distance themselves from the customary set of definitions, images, and notions. Do you think that the notion of 'intellectual cowardice' is justified? And if yes, then why is it so scary to look for new explanations and new meanings?

- I would not say that this is just intellectual cowardice. I think this is too narrow a definition. The human ego has certain qualities and exists in a very complex relationship with the surrounding world. Intellect is that part of a human being which is busy mainly analyzing the outside world. International relations experts analyze the international situation above all else, but I think their perception of the world is overly rationalistic.

Our brain is lazy. So in this sense your question is quite legitimate, but "laziness" is a rather evaluative and sententious notion. Whether the world is rational is a big question. There is no answer to this question for the time being and there will probably never be one. A combination of rational analysis with suspected irrationalism is an eternal problem. And we can feel it now.

So "know thyself" first-in the current time and circumstances. Someone has already said this before me, but to no avail...

- The 'Cold War' is not so bad a term to describe a conflict, both perceived and real. The opponents of its overuse claim that the Cold War was a confrontation between two ideologies, an existential confrontation between two models of the world, two models of worldview. But during the Cold War even in the socialist camp not all considered the Soviet Union a true bearer of Marxist ideas, and they had their reasons. In the Brezhnev era the erosion of communist ideas and their profanation was obvious to any layman...

- Even to Leonid Ilyich himself, I must say. He used to tell his close friend, now late, who was his speechwriter: "Listen, don't use so many quotes from Marx in my speeches. No one will believe that Leonid Brezhnev has read Marx.” 
- Maybe it is good that he didn't. Actually, détente begins when this erosion gains momentum and the standoff of dogmas ends... The Cold War has been praised for allowing the world to work out the basic principles of survival in a conflict, and this is détente. Considering all this, can one say that the Cold War was a war of ideologies or were those ideologies simply used for manipulating masses for the sake of purely utilitarian objectives of classical geopolitics?

- Everything depends on which particular stage of the Soviet communist regime we are talking about. If we are talking about its initial stage, the ideological factor played a fundamental role there, because such communist leaders as Lenin and Trotsky were sincere champions of world revolution, and those ideas were not empty fantasies. Revolutionary processes in the world evolved cyclically, as can clearly be seen since 1848 (even without the Great French Revolution). The Italian Revolutions of 1848 developed, as we all know, into the first pan-European one. Revolutions in the early 20th century also affected almost entire Europe: Austria-Hungary fell apart, Soviet power temporarily won in Hungary, and the Bavarian Republic came into existence... The idea of world revolution is not some nonsense but a strongly ideologized analysis of reality, one of the possible versions of such analysis. Naturally, the Bolsheviks' motto "peace without annexations and without indemnities" was a largely ideological motto even though it did have some geopolitical implications.

Later, this ideological construct eroded. All sects and all ideological groups develop in pretty much the same way from a cohesive group of zealous heroes and martyrs, willing to sacrifice everything they have for the truth stuck in their heads and destined to triumph, to a gradual transformation into a ritual quagmire, which is used solely for preserving or strengthening one's personal and/or narrow group positions. In 1968, the Czechs chanted: "Those who fear opposition fear for their position."

Of course, the pre- and post-war world was largely a geopolitical world cut by Molotov and Ribbentrop under the direction of their leaders, and later by the Allies in Yalta, and so on. It was undoubtedly 
a division of the world between great powers, which the East and the West subsequently covered up with their own ideologies. Some accepted those ideologies to a certain extent and believed in them, others were absolutely cynical, depending on one's personal qualities. But it was a geopolitical construct by three-fourths, and an ideological one by the remaining one-third. Today we can see some of its elements being reproduced.

Some of our theoreticians would probably like to go back into the "beautiful old world," but this can't be done. As Andrei Voznesensky has famously remarked, "Everything eventually comes full circle, but the circle changes." Today geopolitics is no longer the main, let alone the only, factor of human life-both individually and nationally-in the modern world.

\section{- But does this situation require a different, "non-geopolitical," assessment?}

- If we are captivated by traditional geopolitical views, we usually tend to push all the other factors needed for analyzing the outside world into the background and underestimate them even if we admit their existence. But we are in a state where we must take hold of the main link, as Vladimir Lenin stated quite clearly. I would only add that we must not forget the other links which become increasingly less important.

Let's assume that geopolitics is the main link. Philosophers and political scientists like Dugin and the like follow the behests of Admiral Mahan and George MacKinnon and engage in lofty intellectualizing just to say that international relations essentially boil down to continents, countries, geographical location, etc. Naturally, the fact that the United States is surrounded by Mexico on one side and Canada on another affects American policy, and the same goes for Russia which has China on one side and Eastern and Central European countries on another.

But there are many other factors. The factors of space are important, but so are the factors of time. When one talks about geopolitics in terms of the Hundred Years' War, or Ivan the Terrible, or Frederick the Great, not quite understanding that everything is happening in 
a completely different historical and time context, he makes a gross mistake. Especially when it turns out that classical powers are no longer the only agents and factors of international relations and that Internet monopolists or semi-monopolists influence world affairs just as much as major states do.

We can declare this loudly but then we go back to square one: America is such and such, and France is different, even though America is penetrating France, and France is penetrating America, and both are penetrating somewhere else. For some reason, China does not want to quarrel with America not because of geopolitics but because there are many other very serious, contemporary interstate factors-financial, economic, and technological-involved in international relations.

Concentrating on one factor while ignoring all the others is what causes the laziness of thought. But I would say that this laziness is not intentional or criminal, it is intrinsic laziness. It is our second nature.

- Imperfection of man as such ...

- Yes, if you like. The Nietzsche- or Gorky-like superhuman delirium is absolutely alien to me. I believe that being an ant can sound proud only within one anthill, and not even the whole of it.

- Delirium is a good word and it takes us to the next question. When one political leader, be it Trump, Putin, Macron, or Kim Jong-un, is demonized or praised, is this also delirium?

- It takes a lot of imagination to praise Kim Jong-un. Trump obviously has it. Frankly speaking, I personally consider him one of the brightest major international political figures.

- But when politics is reduced to the personality of a politician, followed by extreme assessments - praise or demonization: "All of America's problems are caused by the fact that Russia is aggressive and Putin is its head" or "all of America's problems are caused by the fact that Trump is not a politician but a businessman and a showman"...

- In other words, unlimited personification of each problem. 


\section{- Right. What is behind this?}

- Personification of problems in politics is unavoidable, of course, because politics is a game where the stage belongs to bright people. Sometimes inquisitive spectators try to steal a look behind the wings, into the prompt box or under the stage where all sorts of bizarre things go on... But personification is one of the most complex problems in politics, and who can tell where the will of people ends and the power of things begin? They are intertwined so closely.

Napoleon Bonaparte, one of the brightest politicians and personalities of all times, used to say that politics was fate. There is no doubt that he was overwhelmed by his own personality once and for all, but at the same time he was well aware that politics was fate and there was no way to overbear the power of things or escape it.

Who can prove that Vladimir Ulyanov was a bigger figure than, for example, Sergei Nechayev, the head of People's Retribution and the author of "Revolutionary Catechism," who lived one generation earlier? Nechayev was a man of exceptional will, courage, and personal gallantry, albeit a terrible personality and a key character in Dostoyevsky's The Possessed. But, as Chernyshevsky put it, no change of the scenes occurred during his lifetime, but it occurred twice under Vladimir Ulyanov: he missed one in 1905 and was slightly late for the other in 1917, and yet he managed to catch up and saddle it.

And where is the will of people and where is the power of things here? There is no doubt that the role of personality was a very important factor which contributed to the victory of the Reds over the Whites in the Civil War. The Bolsheviks and their leaders happened to be more capable, bright and dynamic politicians. One must not forget that the main arms manufacturing facilities and depots were controlled by the Reds and located mainly in the two capitals and around them. Finally, arms and men were put together very skillfully and under very opportune slogans. This is why the power of things and the will of people merged together, giving victory to the Reds rather than the Whites. The latter sometimes were just as cruel as the former even though their movement was based on patriotism, courage, honor, and selflessness. And there were some very intelligent 
and bright people among them, like Denikin or Wrangel, but they failed to combine power with will and bring together arms and men filled with aspirations, and eventually lost the bloody civil war.

Combining the will of people with the power of things is the main condition for historical changes. Any revolution, any major sociopolitical change always occurs at two levels. On the one hand, there is a dynamic shift of surface layers, scenes, on the political stage. It was portrayed quite artfully, albeit historically wrongly, by Eisenstein in his film October. Likewise, the taking of the Bastilles is a very graphic and "explosive" episode but very brief and, therefore, lacking in depth.

In a deeper sense, a revolution is a process that takes one, two or three decades, when each cell of society, from one's house, yard and community to the state and even a group of states, changes fundamentally and irreversibly.

This is what a real revolution is. When changes of such magnitude happen, priority should probably be given to the power of things. When revolution reaches its climax, it is the people with their roles and masks who act on the stage, not under or above it, where each individual's abilities amazingly concur with the times and ongoing events. Lenin wrote in October 1917: today it is still early, but it will be late the day after tomorrow.

The same applies to personalities, and the same personality will look different a month from now. Trotsky was in his glory in the fall of 1905 and October 1907, but looked so miserable when those whom he called "epigoni" kicked at him ten years later.

Personification of politics is just a unique combination of personality and time. Some happen to be around at the right time, some don't, and some try to harness slipping time.

- While explaining the essence of politics, you use a lot of theatrical terms. We can recall 20th century French author Guy Debord and his The Society and the Spectacle...

- He was not the first one. Even Shakespeare spoke of something like that. 
- Naturally, but Debord is closer to our times. If we take your line of images and the feeling of confusion among political scientists and politicians, too, the feeling of absurdity enveloping political relations, and the feeling of weakness and lack of ratio needed for full comprehension of events... can one say that politics today is evolving like a big theater of the absurd, which makes it unpredictable and unrationalizable, where we are just spectators and all we can do is sit, watch and enjoy it according to our tickets?

- We cannot do even that or we have to carry out another revolution as soon as possible in order to put an end to all this. I mean a revolution in replacing our imperfect intellect with artificial intelligence.

\section{- Will it help?}

- It probably will in some ways. I keep on repeating that the main problem at the current stage of societal development is the growing gap and conflict between humanism and progress, because progress leads to the loss of human factor in understanding, perceiving and ultimately reorganizing the world. Apparently we have not yet reached the limit of the combined functional capacities of our brain, but its concrete functions increasingly lag behind artificial intelligence in more and more ways.

What has really struck me lately is that artificial intelligence has definitely beaten man in the game of Go. In chess, where there is an incredible variety of choices, calculable variants outnumber intuitive ones. So Garry Kasparov's first loss to artificial intelligence was sad, of course, but quite predictable. When Kasparov drew a tie with a supercomputer for the first time, I sent him a telegram: Dear Garry, thank you for rallying to the defense of primates...

- It was viewed as some sort of existential standoff even back then ...

- Right, but in Go intuition plays a much bigger role than in chess, as far as I understand. All the players say so. But what does this mean? Artificial intelligence can already intuitively react to changes in the situation, which means a gradual convergence, and 
eventually replacement, of this factor in perceiving, understanding and evaluating the world, which we have always ascribed solely to human beings. Where will this lead? Will it lead to full or partial loss of human monopoly on personal contact with the outside world? We do not know this for sure, but it is absolutely obvious that this process is developing at a breathtaking pace...

If we keep on saying that people, who appeared some 30,00040,000 years ago and replaced Neanderthal men, have not changed since then and are now trying to assess the world, including the system of relations between different tribes, countries and states... this kind of mentality is no different from attempts to reevaluate geopolitics to the detriment of all the rest, including the process of reevaluation itself. In reality, while we try to understand the world, there comes the question: Who are we that we are trying to understand the world and what is happening to us? The changing world and one's changing self in this world must be evaluated at the same time. Otherwise, this process may turn into self-deception.

- You say that the advance of artificial intelligence may cause people to lose their human side?

- Meanwhile progress is speeding up. This is a real dilemma: should man feel proud or scared that he is losing monopoly in what he himself proclaimed one of the key principles of his development as a species in the 19th century or probably as far back as the Renaissance?

- Lately philosophers, activists, and publicists of the Orthodoxtraditionalist views, who can probably even be called obscurants, have been actively attacking humanists and enlighteners for having deprived mankind of belief in God. And in this case the computer is depriving humans of humanness. It looks like a self-replicating catastrophic process which leads to the selfdestruction of mankind?

- Yes, but the problem is that we analyze the system of international relations in a somewhat Ptolemaic manner. The only difference is that instead of Earth we place the traditional man in the center of the 
Universe. It's a wonderful Renaissance idea that flourished for a long time. I grew up with such great books as The Children of Captain Grant and The Mysterious Island where people of free will could overcome all problems. As the famous Soviet song goes, "Nothing Will Stop Us, Not at Sea, Not on Land!" Apparently, we are living through a period of critical self-analysis of this Ptolemaic model in assessing our approach towards the outside world as a whole. But we will have to go further. More and more often we come to understand that there are some final, or nearly final, parameters for the "normal" existence of "normal" classical human beings on Earth. Nevertheless we think more about striking a deal or forming a union with someone, correcting the borders, or creating a system of mild and humane, "human," punishment for those who disobey, and believe that everything will be fine.

While we do that, fundamental changes are occurring in the basic parameters. Yet we continue to consider them fundamentally invariable, proceeding from the concept of "Ptolemaic man" based on the omnipotence and power of human beings. As a matter of fact, I am very much convinced that Karl Marx was a deeply religious person and his militant atheism, both in the Judaic and Christian sense, does not deny the fact that he had a religion of his own. He even had the main agent of that religion-Titan Prometheus, who stood against the surrounding world proudly and arrogantly due to his perseverance, dignity, and contempt for the powers that be. In other words, he was a constant and perfect superman.

But today this Prometheism looks very doubtful, because the "superman," like Baron Münchhausen, has got into a quagmire from which he is trying to pull himself out by his own hair, with little success thus far. I think the analysis of international relations must take this factor into account. I would not take the risk of offering new absolute parameters of world perception here, but I do think all the time about where we have come...

All this geopolitics...remains, of course, but it looks like a hen with its head chopped off: the legs keep running and the wings flapping, but no one knows where the head is. 
- Let us try to determine at least one parameter. You have recently addressed this question to a senior diplomat, but he skillfully avoided it ...

- Because he was a diplomat.

- I am not a diplomat and I will use the opportunity to return this question to you. What in your view is the criterion of foreign policy efficiency?

- It depends on which level of this multi-layer Tower of Pisa we stand. If we are talking about a concrete country, our country, where we live and work, I think a foreign policy efficiency criterion is how well it helps facilitate the implementation of the national tasks that have been set to it.

\section{- We call it national interests.}

- That's right, national interests. However, this raises lots of new questions: What is national and what is interest? National is the interest of what? Of the nation as embodied by the state and its structures? Or is national interest what Aleksandr Solzhenitsyn described as the saving of people? We like to repeat his words, and there are certain reserves for doing the saving. Unused reserves, as Leonid Brezhnev called them when he wanted to say that things in the state were not going the way they should.

So if our national interest is, first, in saving the people, and second, in staying abreast of the times and all other elements of international relations (and not only of the state), the question is whether our purely geopolitical approaches help carry out this policy most effectively: there are good states in Latin America and we like them, but we don't like bad states there; the same in Africa, and so on.

We should gradually free foreign policy of rigid subordination to geopolitics and related super-involvement (I would say intuitivelyreactive super-involvement). Geopolitics won't disappear, and we are inside this system, but becoming less engulfed in it is an important task for Russia to tackle. And here I respectfully return to China's experience of the last 35-40 years. What did Deng Xiaoping say at the 
famous plenary meeting of the Communist Party Central Committee in December 1978 when he proclaimed his "four modernizations?" $\mathrm{He}$ said: no extravagance; we remember that ours is a great civilization, but right now we are not proud but modest, we do not teach but learn, and our main task now is investment, the kind of investment that will allow us to catch up with the times. We must keep our armed forces in good shape, including the nuclear factor, because it will allow us to move forward undisturbed. But it is not the priority. Moving forward is the priority and we will have such nuclear factor that will allow us to move forward, not one iota more. More than thirty-five years have passed, and China has not lost but strengthened its sovereignty. And for some reason it has not turned into Russia's younger brother, but on the contrary...

Or look at India from this point of view. Independent India's first leader Jawaharlal Nehru did a great thing-he had led the country to freedom and turned it into a great power and a Non-Aligned Movement leader. But there was no foundation under this greatness, which became apparent quite quickly. That's when less charismatic people came and said: We will act more modestly for the time being and do pretty much the same the Chinese are doing, but in a slightly different way. And what is the result? India is beginning to turn into a great power with a real foundation.

There are also other stories of the same kind, and all of them indicate that time is no less important than space and current geopolitical games which quickly sink into oblivion, giving way to new equally thrilling geopolitical games.

- You say: catching up with the times. But can a nation, a country, alone or in an alliance with others, set the pace for the times, or is it an objective phenomenon and all have to catch up with it anyway?

- Everybody does. If you mean, for example, the United States, many call it a hegemon. The U.S. is indeed the strongest power in the modern world. There have always been strong powers. But then something happened to them. Compare the U.S. after the war and now. Back then it accounted for 55\% of the GWP, today for about 
21-22\%. The situation has changed, and Trump's "Make America Great Again" call is a very interesting formula. The U.S. accuses others of revisionism, but isn't it a revisionist itself?

This is a romantic nostalgia for the past that cannot be brought back.

\section{- Turning to the roots always means revisionism ...}

- "Regaining greatness" means searching for the lost Golden Age. As a matter of fact, this motto is quite communist in substance, not in structure but in substance. In the structure of communism the Golden Age is in the future, whereas here it is in the past, which must be converted into the future. It is not accidental that during George W. Bush's presidency Kissinger called his supporters and his own opponents Trotskyites and advocates of world revolution...

I would put Trumpism in the category of medium-term phenomena along with all the other more or less patriotic "isms" attached to other names we can see around nowadays. The real tendency is that America is not alone. I have named two countries above which will not disappear. And this list goes on.

The Russian problem is that we will have not so much to simulate our greatness as create it. Foreign policy must be subordinated to this task. This is what the long-term national interest is about. But greatness can be built only by peaceful methods. Strange as it may seem, my personal understanding of national interest is quite consonant with Trump's motto: make Russia great again! Make it great, not simulate it!

I have a friend who is a human rights activist. I was the ombudsman for ten years and I still stay in touch with this sphere. He criticizes the government severely for not giving them grants or helping them. This reminds me of a Soviet-era funny story where one respected Soviet woman wrote a complaint to the Politburo: "My husband is a bastard; he has left me for another woman. Bring my husband back to me."

We must clearly understand that isolation and concentration on the sole use of internal resources will lead us nowhere and won't let 
us solve our tasks. This path runs counter to our historical experience since Peter the Great. Even Comrade Stalin, who as we know was quite inclined towards isolation, gave it up as he had come to realize at the end of the 1920s that it was necessary to begin industrialization because there would be a war. There is no doubt that he carried it out using terrible methods by robbing the country and peasants, the bulk of the population in the country, causing people to starve to death, and used the resources thus squeezed out of them to buy key components abroad for industrialization, primarily technologies, including those for the DneproGES hydroelectric station, the GAZ automobile plant, steel mills, and many other enterprises.

- Forced proletarianization ...

- Many think there was an alternative way, but this is a topic for a separate discussion. Stalin's modernization was a rather successful attempt to rebuild Russia's industrial base devastated by war and revolution, using advanced external technologies and solutions. In the postwar period a considerable part of German industry was brought over here as booty, and not only industry but also intellectual capital (and this includes investments in the broad meaning of this word) as well as people, and so on. We used all that to build much of what we had in the late communist period. This cannot be ignored. We must reject the worst GULAG-like methods, but total isolation from the creative world won't do us any good.

Purely theoretically, we can speak about a nuclear war, of course, but even after we have won it (which is incredible all by itself) I am afraid there will be no Golden Age either here or around us.

- It seems there is something else that has become the main issue now-sovereignty and identity, which are closely intertwined. Reassessment of these notions seems to occupy the minds of political scientists, philosophers, and economists. But it is disconcerting that identity is often defined from the contrary, that is, through negative identity: Ukraine is not Russia; Russia is not Europe; East is not West, and so on. 
- Lermontov started it with his "Real men, unlike you lads!" And Kuchma even wrote a book titled Ukraine Is Not Russia.

- You say that as the Non-Aligned Movement leader India did not have the foundation. Maybe it was so because it was some sort of negative identity for the country: "We have not joined, we are different..." But negative identity does not explain what we are like. Do we need to draw a definitive line of demarcation before we unite, as the classic mentioned today said? Or uniting is not necessary after all?

- We won't be allowed to draw any demarcation lines. Life itself will not allow us to do that. How can we draw any demarcation lines in life where all major processes and work are already underway and will continue in many countries, not just one?

Just recently they sort of photographed a black hole. Who did it? Not England, France or China separately; and certainly not Russia, to my deep regret. But it was done because the time had come and this level of cooperation had become available. I think that Trumpism, or Hungarian Orbanism, and so on are important reactive processes in response to the long-term globalization which is taking place in the world both vertically and horizontally, affecting individuals and whole communities. Like any powerful movement, it goes by leaps and bounds, in waves, recoiling and struggling. It hits people, groups and even individual countries, causing indignation and attempts to slow it down.

In other words, this is a process that is well known to us since we know man, or so we think, because in point of fact we don't know much about him at all. But this is a medium-term process, a mediumterm phase of the process, not necessarily very short, but just a phase. I would call it a reaction from some ideologists of globalization who try to run ahead away from reality, from globalization itself. The enthusiasts of globalization are trying to take a giant leap into the future from the current transitional and controversial reality. Like Fukuyama, who said that history had come to an end at the turn of the century because one of the blocs had collapsed and we had come 
to the rational, unitary, fair and good... But it's just nonsense. And he himself realized it later.

People are sincerely at a loss: what kind of globalization is this? First of all, it is unfair because the strong are trying to get a piece of the globalization pie, while globalization tends to turn into the Americanization of the world. Is there such a tendency? There certainly is. There will always be attempts to use any movement of mankind either way for concrete selfish interests of people, groups of people, countries, and so on.

Some believe that these tendencies either are beginning to show in China or will show. The Chinese usually look far ahead-such is the nature of their ancient culture. But does this mean that we should declare a holy war on globalization? I think it will be another classical example of treating dandruff with the guillotine. In fact, this is an effective method because dandruff goes away even though the side effect is much too serious.

Needless to say, the current processes are a retreat. But it is not caused only by the evil will of selfish guys from Wall Street who want to sack money, even though such attempts do exist, but mainly by mankind's objective movement forward. People always hurry ahead. Lenin hurried from the Russian revolution to a world one and further on towards the victory of world communism. Has global communism been built? It has not, but surprisingly huge leaps forward have been made, such as those in Sweden with its social guarantees.

Many things will happen now too. Clearly, the whole of Africa won't be let into Italy, which is right. Everybody must understand that there are certain stages to go through, that there is no formula how to turn Europe into Africa and vice versa, but there is the formula of assistance to Africa that would make such a transformation senseless. This is life and development. As for your question, I have the following answer: We won't be able to get away from globalization because those willing are led to it by fate, and those unwilling are pulled. Those like Trump or Kaczynski come and go, but globalization will end only with the end of human civilization. 
- Then let me ask you the last question. Which trend in world politics in your opinion is the most disturbing one at this point and which one is the most favorable?

- I am very much worried by partial but systematic degradation of nuclear nonproliferation systems, and not only those concerning nuclear weapons but weapons of mass destruction in general. The problem is that technologies get simplified and miniaturized, and so do possibilities for global destruction. This threat is constantly diversified and does not come from states alone any more. Unfortunately, this is also one of the forms of globalization.

\section{- The threat mutates like a virus.}

- Right. It's a virus. And this worries me even more than certain ideological trends like ISIS (banned in Russia), a painful trend but, like all the previous ones, transient. When we talk about terrorism and link it directly to ISIS, we forget that there was a group called Baader-Meinhof in Europe and there were Red Brigades in Italy, which did the same and worried us just as much. All this changes and, like any sect, goes through the stages of ripening, steel-hard passionarity, and eventually gradual dilution and decline. I do not think that the current terrorist challenges will develop into something bigger than that. But these challenges multiplied by the degradation of WMD nonproliferation systems are a very disturbing trend.

What is good is that what was achieved in the previous centuries in terms of arms limitation and readiness (and ability) to hold consultations when an urgent need arises, including closeddoor and very substantive consultations, has not been scrapped completely yet.

This structure is in danger, but it still operates because it was created in the harshest years of the Cold War. It seemed fifty years ago that there could be nothing good after the invasion of the Czech Republic by five Warsaw Treaty countries in 1968. But seven years later, in 1975, the Helsinki accords were signed, those "three baskets," to which the Soviet Union became party. Or take Afghanistan. We overdid it with confrontation there so much that it triggered an emotional reaction 
in response, producing another form of flight ahead from reality_ “a new political thinking": we will get everything done and make a deal right now. This is also a form of collective illusion which runs ahead of its time but does not obstruct its flow. This is how mankind develops. We can't do anything about it.

Although passions sometimes assume exotic forms, I think there will definitely be the next wave of enlightened and mature realism in international relations. It won't come out of the blue but will be based on some of the current and previous achievements. This is what I think. 